\title{
PENGEMBANGAN OBJEK WISATA ALAM UWAE PELLAE DALAM MENINGKATKAN PENDAPATAN RETRIBUSI WISATA DI DINAS PARIWISATA DAN KEBUDAYAAN KABUPATEN SINJAI
}

\section{DEVELOPMENT OF UWAE PELLAE'S NATURAL TOURISM OBJECTS IN INCREASING TOURIST RETRIBUTION INCOME IN THE SERVICE OF TOURISM AND CULTURE, SINJAI REGENCY}

\begin{abstract}
This study aims to provide an overview and explanation of the Development of Uwae Pellae Natural Tourism Objects in Increasing Tourism Retribution Revenues in the Tourism and Culture Office of Sinjai Regency. This type of research uses descriptive qualitative research type. The data technique is observation, interviews with a number of informants. Data analysis using an interactive analysis model. The results show that the development of the Uwwe Pella natural object has succeeded in increasing PAD by a stage of about forty million in one year but does not make a direct and significant contribution to increasing the retribution of the Tourism and Culture Office because until 2020 it is still under the management and supervision of Kampala Village, Sinjai Regency. Several methods of developing a tourist attraction can be seen from the aspect; Criteria that attract tourists (attractions), in the form of beautiful natural scenery, abundant natural hot air sources and good security conditions (2) Criteria for developing tourist areas, in the form of villa construction and renovation of swimming pools for men and women and children (3) The criteria for community welfare show an increase in the surrounding community to participate in tourism object organizations and open kiosk businesses by providing various foods and snacks for visitors.
\end{abstract}

Keywords: development, increased; retribution

\begin{abstract}
ABSTRAK
Penelitian ini bertujuan memberikan gambaran serta penjelasan tentang Pengembangan Objek Wisata Alam Uwae Pellae dalam Meningkatkan Pendapatan Retribusi Wisata di Dinas Pariwisata dan Kebudayaan Kabupaten Sinjai. Jenis penelitian ini menggunakan tipe penelitian deskriptif kualitatif. Teknik pengumpulan data adalah observasi, wawancara terhadap sejumlah informan. Analisis data menggunakan model analisa interaktif. Hasil penelitian menunjukkan bahwa pengembangan objek alam Uwwe Pellaeberhasil meningkatkan PAD dengan penghasilan sekitar empat puluh juta dalam satu tahun namun tidak memberikan kontribusisecara langsung dan signifikan pada peningkatan retribusi Dinas Pariwisata dan Kebudayaan karena sampai pada tahun 2020 masih dalam pengelolaan dan pengawasan Desa Kampala Kabupaten Sinjai. Beberapa metode pengembangan objek wisata dapat dilihat dari aspek; (1) Kriteria menarik minat wisatawan (Attractions), berupa view alam yang indah, sumber air panas alami yang melimpah serta kondisi keamanan yang baik (2) Kriteria pengembangan
\end{abstract}


kawasan wisata, berupa pembangunan villa dan renovasi kolam renang khusus pria maupun wanita dan anak-anak (3) Kriteria kesejahteraan masyarakat menunjukkan peningkatan dengan keterlibatan masyarakat sekitar untuk ikut serta mengelola objek wisata serta membuka usaha kios dengan menyediakan aneka makanan dan cemilan bagi pengunjung.

Kata kunci: pengembangan; objek wisata; retribusi

\section{PENDAHULUAN}

Terkait pengembangan objek wisata alam Uwae Pellae Kabupaten Sinjai harusnya menjadi bagian yang penting dibahas secara bersama dengan instansi terkait, untuk meningkatkan kontribusi pendapatan retribusi serta memajukan pariwisata Kabupaten Sinjai. Pengembangan objek wisata akan berdampak pada Pendapatan Asli Daerah (PAD) daerah itu sendiri. Untuk mendukung hal tersebut maka pemerintah telah mengatur semuanya dalam Perda Kabupaten Sinjai No. 6 Tahun 2017 Tentang Retribusi Tempat Rekreasi dan Olahraga, Undang-Undang Nomor 10 tahun 2009 tentang kepariwisataan, Peraturan Daerah Tentang Rencana Pembangunan Jangka Menengah Daerah Kabupaten Sinjai 2018-2023.

Wisata Permandian Uwae Pellae yang cukup banyak diminati wisatawan domestik ini seharusnya berbanding lurus dengan pendapatan retribusi namun pada kenyataannya belum secara signifikan berkontribusi pada peningkatan PAD Kabupaten Sinjai. Hal ini disebabkan masih terdapat kendala yang menghambat peningkatnya objek wisata Uwae Pellae seperti belum memadainya sumber daya aparatur khususnya bidang teknis kepariwisataan, perencanaan dan pelaksana, serta baik dari segi kualitas maupun kuantitas, dan belum tertatanya objek wisata secara maksimal serta sarana prasarana yang masih kurang sehingga minat wisatawan untuk berkunjung masih rendah, serta terbatasnya anggaran yang tersedia untuk pengembangan objek wisata yang menjadikan retribusi wisata alam Uwae Pellae belum dapat mendongkrak target PAD yang telah ditetapkan. Pernyataan tesebut relevan dengan hasil penelitian Yoeti (2001) yang mengemukakan ada tiga faktor yang menentukan keberhasilan pengembangan kepariwisataan yaitu tersedianya objek dan daya tarik wisata, tertatanya fasilitas sarana dan prasarana sehingga memungkinkan wisatawan mengunjungi suatu 
daerah atau kawasan wisata, yaitu sarana kepariwisataan yang dapat memberikan kenyamanan pelayanan kepada masyarakat, Meskipun di sisi lain sistem promosi/informasi mengenai kepariwisataan Kabupaten Sinjai sekarang ini cukup maju dan terdepan dalam mempromosikan berbagai objek wisata Kabupaten Sinjai, namun kenyataanya objek wisata alam yang cukup potensial untuk dikembangkan seperti Uwae Pellae masih luput dari promosi dinas pariwisata setempat.

Pemberian kewenangan dalam pananganan pajak dan retribusi daerah, diharapkan dapat lebih mendorong pemerintah daerah terus berupaya untuk mengoptimalkan Pendapatan Asli Daerah PAD khusunya yang berasal dari pajak daerah dan retribusi daerah berbagai macam respon timbul dari daerah-daerah untuk meningkatkan PAD melalui pajak daerah, namun kreativitas pemerintah yang berlebihan dan tak terkontrol dalam memungut pajak daerah dan retribusi daerah akan menimbulkan dampak yang merugikan bagimasyarakat.

Sementara itu apabila diperhatikan sistem perpajakan yang dianut oleh banyak negara di dunia maka prinsip-prinsip umum perpajakan daerah pada umumnya tetap sama yaitu harus memenuhi kriteria umum tentang perpajakan daerah sebagai berikut: a) prinsip memberikan pendapatan yang cukup dan elastis artinya dapat mudah naik turun mengikuti naik turunya tingkat pendapatan masyarakat. b) adil dan merata secara vertikal artinya sesuai dengan tingkat kelompok masyarakat sehingga tidak adayang kebal pajak. c) administrasi yang fleksibel artinya sederhana, mudah dihitung, pelayanan memuaskan bagi yang wajib pajak. d) secara politisdapatditerima oleh masyarakat, sehingga timbul motivasi dan kesadaran pribadi untuk membayar pajak (ketaatan membayar pajaknya yang tinggi). e) non distorsi terhadap perekonomian dimana implikasinya pajak atau pungutan akan menimbulkan suatu beban baik bagi konsumen maupun produsen.

Permandian Uwae Pellae berada di kawasan pemukiman warga dengan panorama yang indah di Desa Kampala Kecamatan Sinjai Timur Kabupaten Sinjai. Ditempat inimemiliki sumber air panas dengan suhu mencapai $60^{\circ} \mathrm{C}$ dan kadarbelerangnya 1,5\% yang dipercaya bisa menyembuhkan gatal-gatal dan rematik. permandian ini merupakan objek wisata andalan yang banyak dikunjungi 
oleh wisatawan domestik baik dihari-hari biasa dan akan meningkat pada hari libur untuk memanjakan diri pada permandian Uwae Pellae (air panas) mengalir secara alami di bawah akar pohon beringin dengan diameter sekitar $50 \mathrm{~cm}$ dan terlihat mendidih pada lubang sumber keluaranya air panas dalam sebuah sumur hingga mengeluarkan asap pada kolam permandian sekitar tempat munculnya sumber air panas tersebut.

Keunikan lainya dari Destinasi Wisata Alam Permandian Uwae Pellae adalah banyaknya tali maupun potongan kain yang diikatkan pada ranting maupun akar pohon beringin yang menjadi sumber mata air belerang, Menurut beberapa pengunjung mereka percaya jika menggantung tali atau potongan kain maka permohonan akan segera terkabul dan akan kembali pada tempat tersebut jika harapannya terkabul.

\section{METODE PENELITIAN}

Jenis penelitian yang digunakan adalah penelitian kualitatif, yaitu data yang dinyatakan dalam bentuk kata, kalimat, dan sesuai dengan keadaan, situasi dan kondisi tempat peneliti melakukan penelitian. Tipe penelitian yakni menggunakan penelitian deskriptif dengan maksud berupaya untuk menggambarkan (deskripsi), menjabarkan, mengungkapkan, menjelaskan, menganalisis mengenai pelaksanaan tugas dan fungsi pemerintah dinaspariwisata dan Kebudayaan Kabupaten Sinjai.

Sumber data yakni menggunakan data primer yang diperoleh secara langsung dari penelitian lapangan dengan menggunakan teknik pengumpulan data berupa observasi, dan wawancara sedangkan data Sekunder yang diperoleh melalui dokumen atau arsip yang berkaitan dengan penelitian. Informan yang dipilih, adalah yang dapat memberikan keterangan atau informasi-informasi yang relevan, baik itu berupa peristiwa, orang, serta situasi atau kondisi yang akanditeliti. Data yang diperoleh selanjutnya dianalisis dengan teknik analisidata yang sifatnya kualitatif yang meliputi langkah-langkah reduksi data, penyajian data, serta penarikan kesimpulan guna menjawab permasalahan penelitian. 


\section{HASIL DAN DISKUSI}

Terdapat 6 komponen yang menjadi penetapan struktur dan besarnya tarif di Dinas Pariwisata, Kepemudaan dan Olahraga yaitu, tarif masuk permandian, tarif penyewaan fasilitas, tarif penyewaan alat, tarif masuk kolam utama dan kolam anakanak, tarif masuk lokasi taman satwa/taman bunga, dan tarif sewa tempat untuk penjual. Dengan tarif dan keterangan yang berbeda- beda.

\section{Kriteria Attractions}

Kriteria attractions adalah daya tarik pariwisata atau hal-hal yang menarik perhatian wisatawan yang dimiliki oleh suatu daerah tujuan wisata seperti objek dan daya tarik wisata ciptaan tuhan yang berwujud keadaan alam, flora dan fauna atau berwujud musium, peninggalan purbakala, peninggalan bersejarah, wisata petualangan maupun taman rekreasi dan komplek hiburan/keindahan alam, iklim dan cuaca, kebudayaan, sejarah, sifat kesukuan, kemampuan atau kemudahan berjalan atau ketempat tertentu dan didukung dengan kondisi keamanan dalam objek wisata itusendiri.

Wisata Permandian Uwae Pellae cukup banyak diminati oleh pengunjung wisatawan lokal maupun domestik meskipun belum terekspose secara luas tentang oleh Dinas Pariwisata dan Kebudayaan setempat yang disebabkan objek wisata tersebut belum dikelola langsung oleh Dinas Pariwisata, melainkan masih dalam pengelolaan dan pengawasan Desa Bongki Kampala Kecamatan Sinjai Timur Kabupaten Sinjai.

Sumber air panas dari dasar bebatuan yang muncul dibawah pohon beringin berukuran raksasa, fantasi air panas alami skitar 60 derjat celcius dengan kandungan belerang yang dipercaya oleh masyarakat dapat menyembuhkan luka dan gatal-gatal alergi menjadi daya tarik tersendiri bagi wisatawan. Disamping itu, adanya kepercayaan masyarakat dan tradisi ikat pohon oleh pengunjung dengan menggunakan tali atau potongan kain, masih dipercaya oleh sebagian masyarakat akan terkabulnya keinginan atau harapan yang sekaligus sebagai isyarat bagi pengunjung untuk berkunjung kembali pada objek witasa Uwae Pellae saat harapannya saat berada di lokasi wisata tersebut terkabul oleh sang pencipta 
menjadi keunikan tersendiri bagi para wisatawan.

\section{View Keindahan Alam}

Permandian Uwae Pellae dengan view panorama alam yang alami dengan lokasi wisata yang dikelilingi oleh pegunungan serta air sungai yang mengalir di sekitar kolam permandian yang terdiri atas kolam renang khusus Pria dengan kedalaman 2,5meter dan kolam renang khusus wanita dan anak-anak dengan tingkat kedalaman 1 meter menambah kesan eksotik pada objek wisata tersebut terutama di pagi hari atau sore hari. Selain itu, objek wisata sudah dilengkapi dengan tiga buah villa sebagai ruang istrahat dan makan sembari bersantai menikmati pemandangan alam oleh para wisatawan.

Meskipun masih dalam rencana penambahan fasilitas berupa mushollah (tempat ibadah) dan aula untuk tempat pertemuan bagi dinas terkait untuk keperluan tertentu. Selain itu, dibutuhkan penambahan toilet dan ruang ganti secara terpisah antara pengunjung pria dan wanita untuk meningkatkan kenyamanan pengunjung. Mengaitkan observasi di lapangan dengan kerangka pikir menurut Spillane (1994), yaitu dalam mengukur tingkat kesuksesan pariwisata di Indonesia harus meliputi adanya view atau objek pemandangan yang menarik bagi wisatawan. Dan hal itu terdapat keselarasan atau sejalannya pendapat Spillane dengan penelitian di lapangan membuktikan bahwa banyaknya peminat dari wisatawan untuk mengunjungi permandian Uwae pellae karena dengan adanya view yang menarik sehingga wisatawan meminati objek wisata tersebut.

\section{Kondisi Keamanan Yang Baik}

Kondisi keamanan yang baik adalah daya tarik pariwisata atau hal-hal yang menarik perhatian wisatawan yang dimiliki oleh suatu daerah tujuan wisata seperti kenyamanan dalam berwisata tanpa ada gangguan dan fasilitas yang aman ke suatu tempat dengan ke tempat objek wisata tertentu atau yang lainnya. Terkait kondisi keamanan di destinasi permandian Uwae Pellae sangat aman dan kondusif, keamanan daerah sekitar dipantau langsung oleh tokoh masyarakat setempat yang dilibatkan lansung dalam pengelolaan objek wisata bagian bagi karcis bagi pengunjung. Selain itu, telah disiapkan tenaga khusus untuk menolong jika terjadi 
kecelakaan bagi pengunjung khususnya bagi yang tidak bisa berenang.Hal ini dimaksudkan sebagai bentuk antisipasi terjadinya kecelakaan pada pengunjung atau wisatawan.

Dengan kenyamanan dan keamanan diharapkan dapat meningkatkan jumlah pengunjung atau wisatawan sehingga dapat meningkatkan retribusi wisata alam Uwae Pellae yang akan berdampak pada peningkatan kontribusi APBDes Desa Kampala dan secara lebih lanjut berdampak pada peningkatan PAD Kabupaten Sinjai.

\section{Kriteria Pengembangan Kawasan Wisata}

Pengembangan kawasan wisata adalah salah satu cara untuk membuat suatu objek wisata menjadi menarik dan dapat membuat para pengunjung tertarik mengunjunginya pengembangan dilakukan baik dalam objek wisata maupun fasilitas- fasilitas yang ada dalam objek wisata tersebut.

Sebagai objek wisata alam dengan berbagai keunikan dan daya tarik yang mengandalkan keindahan panorama alam sangat berpotensi untuk dikembangkan dengan menambah fasilitas berupa toilet dan kamar ganti secara terpisah antara pengunjung pria dan wanita, villa untuk tempat istrahat pengunjung, mushollah untuk pengunjung yang akan melaksanakan ibadah dan aula untuk keperluan tertentu dalam rangka menunjang kenyamanan pengunjung serta pentingnya menjaga kebersihakn sekitar tempat wisata untuk mendukung potensi alami berupa keasrian objek wisataUwae Pellae Desa Kampala.

\section{Objek Wisata}

Objek Wisata adalah perwujudan dari ciptaan manusia, tata hidup, seni budaya, serta sejarah bangsa dan tempat atau keadaan alam yang mempunyai daya tarik untuk dikunjungi wisatawan Objek permandian Uwae Pellae sudah dilakukan pengembangan objek wisata dengan adanya renovasi kolam renang untuk mendukung spot-spot foto bagi pengunjung serta penambahan gazebo-gazebo dan villa serta didukung dengan pembangunan jalan beton menujuobjek wisata turut mendukung peningkatan pengunjung karena adanya kemudahan jarak tempuh menuju lokasi wisata tersebut. 
Banyaknya pengunjung yang datang untuk berwisata di permandian Uwae Pellaeuntuk menikmati segala objek yang ada di destinasi wisata tersebut. Adapun pengunjung atau wisatawan yang datang paling banyak hari-hari libur dan harihari besar, hal ini di dukungdengan pernyataan pengelola objek wisata bahwa lahan parkir di hari-hari tertentu itu tidak dapat menampung jumlah kendaraan dari pengunjung yangdatang, namun setiap harinya tidak menjadikan tempat ini sepi dari pengunjung. Objek wisata alam Uwae Pellae sudah memiliki objek yang menarik dan sudah dilakukan pula pengembangan objek wisata dalam memikat perhatian wisatawan atau pengunjung untuk datang berwisata ke tempat tersebut.

\section{Sarana Dan Prasarana Wisata}

Sarana \& prasarana wisata adalah seperangkat alat yang digunakan untuk suatu kegiatan, alat tersebut bisa berupa alat utama atau alat yang yang membantu proses kegiatan, sehingga tujuan dari kegiatan tersebut dapat tercapai. Sarana prasarana terkait pelayanan kepada pengunjung di objek wisata alam Uwae Pellae cukup memadai, meskipun masih butuh tambahan fasilitas berupa; Aula untuk ruang pertemuan dan mushollah atau tempat ibadah serta toilet dan ruang ganti pakaian secara terpisah untuk pengunjungpria dan wanita masih dalam tahap rekomendasi yang disebabkan keterbatasan anggaran untuk pengembangan wisata berupa tambahan fasilitas karena belum masuk prioritas pembangunan di Desa Kamapala yang rencananya akan dianggarkan pada tahun 2021 mendatang Harusnya dengan objek wisata alam Uwae Pellae yang menarik harusnya di dukung dengan fasilitas berupa sarana prasarana yang memadai agar pengunjung betah untuk menikmati suasana objek wisata yangada.

Sehingga dengan peningkatan objek wisata akan berbanding lurus dengan meningkatkan APBDes dan selanjutnya akan bermitra dengan Dinas Pariwisata untuk mengelolah objek wisata Uwae Pellae sehingga lebih lanjutberkontribusi pada peningkatan PAD Kabupaten Sinjai.

\section{Pasar Dan Promosi Wisata}

Pemasaran dalam bidang promosi wisata sangat diperlukan karena dengan adanya pemasaran objek wisata tersebut menjadi dikenal masyarakat luas dan 
dapat menarik banyak wisatawan asing untuk datang berkunjung ke objek wisata. Terkait pasar promosi wisata di Kabupaten Sinjai sudah tersebar di berbagai media sosial seperti tongke-tongke, pantai galau, pelabuhan larea-rea dan sebagainya. Selain itu dapat dilihat melalui internet. Namun, untuk objek wisata alam Uwae Pellae masih tergolong sepi dari pemberitaan maupun sosialisasi.

Jika terdapat beberapa foto di media social biasanya hanya sebatas koleksi pribadi pengunjung. Hal ini disebabkan oleh fasilitas yang masih terbatas serta masih terbatasnya ruang sosialisasi yang dilakukan oleh pihak pengelola untuk mengekspose berbagai potensi dan keindahan alam yang terdapat pada objek wisata alam Uwae Pellae yang terletak di Desa Kampala Kecamatan Sinjai Timur Kabupaten Sinjai.

\section{Kriteria Kesejahteraan Masyarakat}

Kriteria kesejahteraan masyarakat mempunyai pengaruh yang signifikan pada sejumlah sektor ekonomis termasuk transportasi, penjual eceran, usaha grosir, dll, salah satu isu yangpentingadalah pengaruh dari pariwisata terhadap kesenian dan kerajinan.

Selain membuka lapangan pekerjaan bagi warga sekitar, pendapatan merupakan manfaat pokok dari pariwisata bagi masyarakatsetempat atau lokal, pengeluaran masyarakat merupakan pendapatan langsung dan melalui akibat penggandaakan dapat memperbesar pendapatan tak langsung, sehingga pendapatanyang diciptakan akan sangat besar sebagaimana dengan pekerjaan akibat yang pasti sulit ditentukan secara teoritis dan akan bergantung pada struktur perekonomian lokal dan industripariwisata.

Dengan adanyaobjek wisata Uwae Pellae, sebagaian masyarakat berinisiatif dengan ikut berpartisipasi sekaligus ingin meningkatkan ekonomi mereka dengan berjualan atau membuka usaha disekitaran objek wisata, dan untuk pedagang yang sudah lama berjualan ditempat tersebut menjelaskan bahwa pendapatan mereka sudah meningkat pula semenjak adanya pengembangan objek wisata, sudah memberi dampak pada peningkatan perekonomian masyarakat sekitaran objek wisata meskipun belum secara signifikan disebabkan inovasi warga setempat untuk 
membuat kerajinan untuk dijual untuk ole-ole pengunjung juga masih terbatas, jualan umumnya hanya seputar makanan dan cemilan.

Faktor pendukung pengembangan objek wisata alam Uwae Pellae yaitu: a) Panorama Alam yang Indah, Sejuk dan Masih Asli/Alami ditambah sungai yang mengalir disepanjang lokasi objek wisata dengan dikelilingi pemandangan gunung dan hamparan sawah yang hijau turut memperindah panorama alam Uwae Pellae. b). Selain itu, Keindahan alam didukung dengan sumber air panas Sumber mata air panas yang jernih dan melimpah. Suhu airnya mencapai $60^{\circ}$ Celcius, ditambah kandungan sulfur dengan kadar belerang mencapai 1,5 persen yang berkhasiat menyembuhkan penyakit kulit, rematik, dan gatal-gatal. Sungai mengalir dibawah pohon beringin dengan ukuran besar dan rindang di sekitar objek wisata merupakan daya tarik tersendiri bagi wisatawan. c) Kondisi Keamanan yang Baik. Keamanan objek wisata Permandian Uwae Pellae cukup terjamin karena melibatkan warga sekitar termasuk tenaga yang pandai berenang untuk membantu warga jika terjadi kecelakaan saat berada pada kolam permandian maupun sungai disekitar lokasi wisata menjadi tanggungjawab bersama seluruh warga setempat untuk menjaga objek wisata tersebut sebagai aset desa.

Keamanan diperlukan untuk menjaga barang-barang pengunjung yang ditinggal bermain ataupun berjalan-jalan di sekitar objek dari tindakan pencurian yang dilakukan oleh oknum yang tidak bertanggung jawab.Selain itu khusus di hari libur seperti Hari Raya jumlah pengunjung dapat meningkat menjadi dua kali lipat sehingga penjagaan keamanaan juga ditingkatkan.

Meskipun demikian, masih terdapat beberapa faktor penghambat dalam pengembangan objek wisata Uwae Pellae yaitu: a) Keterbatasan Anggaran untuk Biaya Sarana dan Prasarana Objek Wisata. Dana pengembanga dan pembangunan Objek Wisata Pemandian Uwae Pellae masih terbatas mengingat belum masuk daftar anggaran APBDes membuat pembangunan dan pengembangan Objek Wisata tersendat. Namun menurut keterangan pemerintah setempat akan dianggarakan kembali pada APBDes 2021 mendatang. b) Lokasi Jauh dari Pusat Kota. Letak Objek Wisata Pemandian Uwae Pellaecukup jauh dari pusat kota dan dari jalanan raya 
menuju ibu kota Kabupaten Sinjai dengan kondisi jalan yang berbelok-belok dan beberapa pendakian yang cukup tajam dan terjal sehingga beberapa pengunjung kadang memilih turun dari kendaraan dan memilih berjalan kaki beberapa meter untuk mencapai lokasi objek wisata Uwae Pellae. c) Sarana dan Prasarana yang masih kurang memadai di objek wisata alam Uwae Pellae seperti Air bersih, Area Parkir, Guest House Villa dengan jumlah unit yang masih terbatas, Gazebo, Toilet/WC dan kamar gantipakaian serta aula pertemuan dan mushollah menjadi hal penting yang harus menjadi pertimbangan dalam pengembangan pada objek wisata Uwae Pellae tahun anggaran 2021 mendatang.

\section{KESIMPULAN}

Berdasarkan hasil penelitian maka dapat disimpulkan sebagai berikut: (1) Pengembangan Objek Wisata Alam Uwae Pellae berkontribusi secara signifikan dalam meningkatkan Pendapatan Asli Daerah (PAD) dengan menyumbang skitar empat puluh juta/ tahun pada APBDes Desa Kampala. (2). fasilitas berupa sarana dan prasarana yang belum memadai disebabkan oleh keterbatasan anggaran untuk pengembangan objek wisata Uwae Pellae karena belum masuk anggaran APBDes tahun 2019-2020 dan akan dianggarakan kembali pada tahun 2021 mendatang dengan pola pengelolaan objek wisata mitra tiga desa yang berbatasan langsung dengan objek wisata yaitu Desa Kampala, Desa Bongki Lengkese dan Desa Salohe untuk mengembangkan objek wisata secara lebih luas sekaligus mempererat kembali kerjasama tiga desa dalam menjaga aset desa dan potensi lokal yang terdapat dalam permandian Uwae Pellae Desa Kampala Kecamatan Sinjai Timur Kabupaten Sinjai. oleh Dinas Pariwisata, Kepemudaan dan Olahraga dengan melakukan pengembangan wahana bermain, berupa spot-spot foto, kondisi keamanan yang baik dan lain-lain hal ini digunakan guna meningkatkan daya tarik pengujung pada objek wisata alam lejja yang sekaligus berdampak pada peningkatan retribusi wisata. (2) Ada beberapa faktor yang dapat mendukung peningkatan objek wisata dalam meningkatkan retribusi wisata diantaranya Panorama Alam yang Indah, Sejuk dan masih asli atau alami, sumber air panas yang melimpah, kondisi keamanan yang baik. Sementara itu disamping adanya faktor 
pendukung masih terdapat beberapa faktor penghambat dalam pengembangan objek wisata alam lejja yaitu keterbatasan anggaran untuk biaya pengembangan objek wisata sehingga sarana dan prasarana masih terbatas, lokasi jauh dari pusatkota.

\section{REFERENSI}

Abdillah, A., Deliarnoor, N. A., \& Yuningsih, N. Y. (2020). The Position of Auxiliary Organ in Government System of West Java Provincial Government. 1(2), 6781. DOI: https://doi.org/10.46507/jcgpp.v1i2.11

Bastian. (2001). Akuntansi Sektor Publik Yogyakarta: Penerbit BPFE, Universitas Gajah Mada.

Feldman. (2008). Tentang Pengertian Pajak. Jakarta: PT, Raja Grafindo Persada.

Terry., G. R. (2013). Prinsip PrinsipManajemen. Jakarta: Erlangga

Mardiasmo. (2002). Perpajakan Edisi Revisi. Yogyakarta: Penerbit Andi Offset.

Nasrullah. (2015). "Strategi Pengembangan Objek Wisata Permandian Air Panas Lejja Dalam Meningkatkan Kunjungan Wisatawan Di Kabupaten Soppeng Sulawesi-Selatan". Volume 2 Diakses pada Hari Minggu, 25 Agustus 2019, Pukul 23.28 WITA.

Samudra. (1995). Retribusi Perpajakan Pungutan Langsung Dari Pemerintah Daerah Jakarta: PT Gramedia PustakaUtama.

Siahaan. (2010). Pajak Daerah dan Retribusi Daerah Edisi Revisi Jakarta: Rajawali Pers.

Spillane., S. J. (1994). Dalam Buku Pariwisata Indonesia.Yogyakarta: Penerbit Kanisius.

Yoeti. (2001). Perencanaan dan Pengembangan Pariwisata. Jakarta: PT Pradnya Paramita.

Yani. (2002) Hubungan keuangan antar pemerintah daerah dan pusat : Jakarta. PT, Grafindo. 